This item was submitted to Loughborough's Research Repository by the author.

Items in Figshare are protected by copyright, with all rights reserved, unless otherwise indicated.

\title{
Time-varying rare disaster risks, oil returns and volatility
}

\section{PLEASE CITE THE PUBLISHED VERSION}

https://doi.org/10.1016/j.eneco.2018.08.021

\section{PUBLISHER}

(c) Elsevier

\section{VERSION}

AM (Accepted Manuscript)

\section{PUBLISHER STATEMENT}

This paper was accepted for publication in the journal Energy Economics and the definitive published version is available at https://doi.org/10.1016/j.eneco.2018.08.021.

\section{LICENCE}

CC BY-NC-ND 4.0

\section{REPOSITORY RECORD}

Demirer, Riza, Rangan Gupta, Tahir Suleman, and Mark Wohar. 2018. "Time-varying Rare Disaster Risks, Oil Returns and Volatility". figshare. https://hdl.handle.net/2134/35674. 


\section{Time-Varying Rare Disaster Risks, Oil Returns and Volatility ${ }^{\#}$}

\section{Introduction}

Crude oil can be regarded perhaps as the most important commodity given its influential role in the world economy relative to other commodities, particularly in terms of its causal effects on recessions (Hamilton, 1983, 2008, 2009, 2013; Elder and Serletis, 2010) and inflation (Stock and Watson, 2003). Additionally, oil is indispensable for the industrial, transportation, and agricultural sectors, whether used as feedstock in production or as a surface fuel in consumption (Mensi, et al., 2014). Consequently, there is a vast literature on the oilstock market relationship, suggesting that oil price shocks significantly impact stock returns and that these shocks contain information that can be transmitted to the stock market (see e.g. Jones and Kaul, 1996; Sadorsky, 1999; Jimenez-Rodriguez and Sanchez, 2005; Basher and Sadorsky, 2006; Driesprong et al., 2008; Nandha and Faff, 2008; Apergis and Miller, 2009; Kilian and Park, 2009; Miller and Ratti, 2009; Chen, 2010; Arouri and Rault, 2011; Basher, Haug, and Sadorsky, 2012; Cunado and Perez De Gracia, 2014; and Alsalman and Herrera, 2015). From an economic perspective, given the intricate relationship between the real economy and financial markets through expectations of cash flows and profitability of firms, one can argue that the effect of oil price shocks on the stock market is partially driven by the increased uncertainty in real economic activity, which in turn reduces investment, consumption and aggregate production (see Elder and Serletis, 2010 and Jo, 2014).

In another strand of the literature, however, motivated by the failure of theoretical pricing models to replicate the level, volatility and countercylicality of equity risk premia, a growing body of work has focused on time-varying disaster risks as a factor that can explain the high excess returns and volatility observed in the stock market. Following the early work of Rietz

\footnotetext{
\# We would like to thank two anonymous referees for many helpful comments. However, any remaining errors are solely ours.
} 
(1988), a number of theoretical and empirical papers have recently provided evidence of the predictive power of rare disaster risks for excess returns and volatility in financial markets (see for example, Barro, 2006, 2009; Gourio, 2008a, b, 2012; Barro and Ursúa, 2008, 2009, 2012; Barro and Jin, 2011; Berkman et al., 2011, 2017; Gabaix, 2012; Nakamura et al., 2013; Wachter 2013; Farhi and Gabaix, 2016; Manela and Moreira, 2017). While Gourio (2012) argues that an increase in the probability of a disaster creates a collapse of investment and consequently drives the risk of a recession, Wachter (2013) relates the time-varying risk of rare disasters to consumption shocks, which in turn drives excess returns and volatility in the stock market. Similarly, Gabaix (2012) proposes a model that combines time-variation in the probability of a rare disaster with time-variation in the degree to which dividends respond to a disaster in order to explain the excess volatility puzzle in stock returns. Similarly, using global political instability as a proxy for rare disaster risk, Berkman et al. (2017) document a positive intertemporal relation between disaster probability and the market risk premium. Further focusing on asset pricing implications, Berkman et al. (2011) show that time-varying rare disaster risks are also priced in the cross-section of stock returns, implied by higher returns observed for industries that are more crisis risk sensitive.

Given the overwhelming evidence on the stock-oil market relationship as well as a significant effect of disaster risks on stock market excess returns and volatility, a natural research question is whether such a relationship exists between time-varying disaster risks and oil return dynamics. Following the arguments of Barro, (2006, 2009), Gourio (2012), and Wachter (2013), if uncertainty regarding the probability and size of disasters leads to a great deal of uncertainty in terms of investment growth or consumption patterns, then considering the suggestion by Bernanke (2016) that both oil and stock markets tend to move together as they both react to a common factor reflecting global aggregate demand, one obvious channel 
that links disaster risks to oil market movements is the potential effect of rare disasters on growth expectations for both output and consumption.

A second channel through which disaster risks can affect oil return dynamics is via its contribution to jump risk in oil prices. While the presence of jump risk driving stock and bond returns is well documented in the literature (e.g. Maheu and McCurdy, 2004; Dunham and Friesen, 2007; Huang and Tauchen, 2005; Maheu et al. 2013 and Guo et al., 2016), there is growing evidence suggesting that jumps account for a large part of the variation in crude oil prices and a substantial part of the risk premium in oil derivatives prices as a result of jumps (e.g. Larsson and Nossman, 2011; Christoffersen et al., 2016; Baum and Zerilli, 2016). In the context of stock returns, Wachter (2013) relates time-varying disaster probabilities to large instantaneous changes, i.e. jumps, in aggregate consumption. Suggesting that the equity market premium is partially driven by the comovement of agents' marginal utility and the price process for stocks in times of disaster (i.e. jump risk), Wachter (2013) shows mathematically that timevarying disaster risk contributes to the equity premium in the form of compensation for jump risk. Given this perspective, one can argue that time-varying rare disaster risks also contribute to the presence of jumps in oil excess returns in the form of a compensation for consumption shocks such that an increase in the risk of rare disasters increases return and volatility in the oil market. To that end, the analysis can provide insight to the effect of oil price shocks on stock market returns and volatility from a novel angle.

The goal of this paper is to examine the predictive power of rare disaster-risks for the return and volatility dynamics of West Texas Intermediate (WTI) oil prices using a long span of historical data over the period 1918:01-2013:12. In the process, we contribute to the literature on rare disaster risks and financial markets from a commodity market perspective by focusing on crude oil. To that end, given the evidence in Berkman et al. (2011) that industries that are more sensitive to crisis risks yield higher returns, our direct focus on crude oil can 
provide valuable insights as to whether the crisis risk premium on particular industries are channelled via their sensitivity to oil price fluctuations. Furthermore, knowledge of the factors (in this case, rare disaster risks) that drive oil market returns and volatility is likely to constitute valuable information for economic agents including those who price and trade derivatives contracts underlying energy assets.

To achieve our objective, we conduct predictability analysis based on the $k$-th order nonparametric causality-in-quantiles test recently developed by Balcilar et al. (2016a). This test studies higher order causality over the entire conditional distribution and is inherently based on a nonlinear dependence structure between the variables, as captured by data-driven nonparametric functions. The nonparametric causality-in-quantiles test of Balcilar et al. (2016a) combines elements of the test for nonlinear causality of $k$-th order developed by Nishiyama et al. (2011) with the causality-in-quantiles test developed by Jeong et al. (2012) and, hence, can be considered to be a generalization of the former. The causality-in-quantile approach has the following three novelties: Firstly, it is robust to misspecification errors as it detects the underlying dependence structure between the examined time series, which could prove to be particularly important as it is well known that oil returns display nonlinear dynamics (Balcilar et al., (2016a)) - something that we show to be the case formally via statistical tests in our case as well. Secondly, via this methodology, we are able to test not only for causality-in-mean (1st moment), but also for causality that may exist in the tails of the joint distribution of the variables, which in turn, is important if the dependent variable has fat-tails - a feature we show below to hold for oil returns. Finally, we are also able to investigate causality-in-variance and, thus, study impact on volatility. Such an investigation is imporant because, during some periods, causality in the conditional-mean may not exist while, at the same time, higher-order interdependencies may turn out to be significant. 
Note that, other standard nonlinear causality tests (for example, Hiemstra and Jones (1994), and Diks and Panchenko $(2005,2006))$ and GARCH models could have also been used to analyze the impact of disaster risks on oil returns and/or volatility, but these approaches rely on conditional-mean based estimation, and hence fail to capture the entire conditional distribution of oil returns and volatility - something we can do with our approach. In the process, our test is a more general procedure of detecting causality in both returns and volatility simultaneously at each point of the respective conditional distributions. Hence, we are able to capture existence or non-existence of causality at various phases (bear (lower quantiles), normal (median) and bull (upper quantiles)) of the oil market. Being a more general test, our method is more likely to pick up causality when conditional mean-based tests might fail to do so. In addition, since we do not need decide on the number of regimes as in a Markov-switching model, and can test for causality at each point of the conditional distribution characterizing specific regimes, our test also does not suffer from any misspecification in terms of specifying and testing for the optimal the number of regimes. Finally, the volatility process and its relationship with the disaster risks, based on GARCH models, would be model contingent depending upon which model of the GARCH family we use and would not be model-free as in our nonparametric approach, where the relationship between, returns and volatility with disaster risks is purely data-driven.

Given the argument by Wachter (2013) that time-varying disaster risks contribute to excess returns and volatility in the form of a jump component in the price process, the nonparametric causality tests that we employ in our empirical tests provide an appropriate approach as it allows us to test for the impact of disaster risks on both oil returns and volatility, while accounting for possible nonlinearities in the relationship between oil market movements and changes in disaster probabilities. To the best of our knowledge, this is the first paper that evaluates the predictive power of rare disaster risks for crude oil returns and volatility based 
on a nonparametric causality-in-quantiles framework. Consistent with the evidence for the stock market, we show that rare disaster risk proxies strongly predict both returns and volatility for oil, with stronger causal effects observed at the lower ends of their respective conditional distributions, suggesting that rare disaster risks potentially contribute to jump risk in oil returns. The findings also suggest that the effect of oil price shocks on stock market return dynamics could partially be channelled via the time-variation in disaster risk probabilities that commonly affects both the stock and oil price processes.

The rest of this paper is organized as follows: Section 2 describes the econometric frameworks involving the higher-moment nonparametric causality-in-quantiles test, and the (GARCH-based) measure of volatility. Section 3 presents the data and discusses the empirical results. Finally, Section 4 concludes.

\section{Econometric Framework}

In this section, we briefly present the methodology for the detection of nonlinear causality via a hybrid approach as developed by Balcilar et al. (2016a), which in turn is based on the frameworks of Nishiyama et al. (2011) and Jeong et al. (2012). We start by denoting oil returns by $y_{t}$ and the predictor variable (in our case, the dummies capturing various types of rare disaster risk-related events- discussed in detail in the next section) as $x_{t}$. We further let $Y_{t-1} \equiv\left(y_{t-1}, \ldots, y_{t-p}\right), \quad X_{t-1} \equiv\left(x_{t-1}, \ldots, x_{t-p}\right), \quad Z_{t}=\left(X_{t}, Y_{t}\right) \quad$ and $\quad F_{y_{t} \mid Z_{t-1}}\left(y_{t}, Z_{t-1}\right) \quad$ and $F_{y_{t} \mid Y_{t-1}}\left(y_{t}, Y_{t-1}\right)$ denote the conditional distribution functions of $y_{t}$ given $Z_{t-1}$ and $Y_{t-1}$, respectively. If we let denote $Q_{\theta}\left(Z_{t-1}\right) \equiv Q_{\theta}\left(y_{t} \mid Z_{t-1}\right)$ and $Q_{\theta}\left(Y_{t-1}\right) \equiv Q_{\theta}\left(y_{t} \mid Y_{t-1}\right)$, we have $F_{y_{t} \mid Z_{t-1}}\left\{Q_{\theta}\left(Z_{t-1}\right) \mid Z_{t-1}\right\}=\theta$ with probability one. As a result, the (non)causality in the $\boldsymbol{\theta}$-th quantile hypotheses to be tested are:

$$
\begin{aligned}
& H_{0}: P\left\{F_{y_{d} Z_{t-1}}\left\{Q_{\theta}\left(Y_{t-1}\right) \mid Z_{t-1}\right\}=\theta\right\}=1, \\
& H_{1}: P\left\{F_{y_{t} \mid Z_{t-1}}\left\{Q_{\theta}\left(Y_{t-1}\right) \mid Z_{t-1}\right\}=\theta\right\}<1 .
\end{aligned}
$$


Jeong et al. (2012) use the distance measure $J=\left\{\varepsilon_{t} E\left(\varepsilon_{t} \mid Z_{t-1}\right) f_{z}\left(Z_{t-1}\right)\right\}$, where $\varepsilon_{t}$ is the regression error term and $f_{z}\left(Z_{t-1}\right)$ is the marginal density function of $Z_{t-1}$. The regression error $\varepsilon_{t}$ emerges based on the null hypothesis in (1), which can only be true if and only if $E\left[1\left\{y_{t} \leq Q_{\theta}\left(Y_{t-1}\right) \mid Z_{t-1}\right\}\right]=\theta$ or, expressed in a different way, $1\left\{y_{t} \leq Q_{\theta}\left(Y_{t-1}\right)\right\}=\theta+\varepsilon_{t}$, where $\mathbf{1}\{\cdot\}$ is the indicator function. Jeong et al. (2012) show that the feasible kernel-based sample analogue of $J$ has the following format:

$$
\hat{J}_{T}=\frac{1}{T(T-1) h^{2 p}} \sum_{t=p+1}^{T} \sum_{s=p+1, s t}^{T} K\left(\frac{Z_{t-1}-Z_{s-1}}{h}\right) \hat{\varepsilon}_{t} \hat{\varepsilon}_{s} .
$$

where $K(\cdot)$ is the kernel function with bandwidth $h, T$ is the sample size, $p$ is the lag order, and $\hat{\boldsymbol{\varepsilon}}_{\boldsymbol{t}}$ is the estimate of the unknown regression error, which is given by

$$
\hat{\varepsilon}_{t}=1\left\{y_{t} \leq Q_{\theta}\left(Y_{t-1}\right)\right\}-\theta
$$

$\hat{Q}_{\theta}\left(Y_{t-1}\right)$ is an estimate of the $\theta^{\text {th }}$ conditional quantile of $y_{t}$ given $Y_{t-1}$, and we estimate $\hat{Q}_{\theta}\left(Y_{t-1}\right)$ using the nonparametric kernel method as

$$
\hat{Q}_{\theta}\left(Y_{t-1}\right)=\hat{F}_{y_{t} \mid Y_{t-1}}^{-1}\left(\theta \mid Y_{t-1}\right)
$$

where $\hat{F}_{y_{t} \mid Y_{t-1}}\left(y_{t} \mid Y_{t-1}\right)$ is the Nadarya-Watson kernel estimator given by

$$
\hat{F}_{y_{t} \mid Y_{t-1}}\left(y_{t} \mid Y_{t-1}\right)=\frac{\sum_{s=p+1, s t t}^{T} L\left(\left(Y_{t-1}-Y_{s-1}\right) / h\right) 1\left(y_{s} \leq y_{t}\right)}{\sum_{s=p+1, s+t}^{T} L\left(\left(Y_{t-1}-Y_{s-1}\right) / h\right)},
$$

with $L(\cdot)$ denoting the kernel function and $h$ the bandwidth.

As an extension of Jeong et al. (2012)'s framework, Balcilar et al. (2016a) develop a test for the second moment which allows to test the causality between the various disaster riskrelated dummies and oil return volatility. Adapting the approach in Nishiyama et al. (2011), higher order quantile causality can be specified in terms of the following hypotheses as: 


$$
\begin{array}{ll}
H_{0}: P\left\{F_{y_{t}^{k} \mid Z_{t-1}}\left\{Q_{\theta}\left(Y_{t-1}\right) \mid Z_{t-1}\right\}=\theta\right\}=1 & \text { for } k=1,2, \ldots, K \\
H_{1}: P\left\{F_{y_{t}^{k} \mid Z_{t-1}}\left\{Q_{\theta}\left(Y_{t-1}\right) \mid Z_{t-1}\right\}=\theta\right\}<1 & \text { for } k=1,2, \ldots, K
\end{array}
$$

We can integrate the entire framework and test whether $x_{t}$ Granger causes $y_{t}$ in quantile $\theta$ up to the $k^{\text {th }}$ moment using Eq. (7) to construct the test statistic in Eq. (6) for each $k$. The causality-in-variance test can then be calculated by replacing $y_{t}$ in Eqs. (3) and (4) with $y_{t}^{2}$ - measuring the volatility of oil returns. However, one can show that it is difficult to combine the different statistics for each $k=1,2, \ldots, K$ into one statistic for the joint null in Eq. (7) because the statistics are mutually correlated (Nishiyama et al., 2011). Balcilar et al. (2016a), thus, propose a sequential-testing method as described in Nishiyama et al. (2011). First, as in Balcilar et al. (2016a), we test for the nonparametric Granger causality in the first moment (i.e. $k=1)$. Nevertheless, failure to reject the null for $k=1$ does not automatically lead to no-causality in the second moment. Thus, we can still construct the test for $k=2$, as discussed in detail in Balcilar et al. (2016a).

The empirical implementation of causality testing via quantiles entails specifying three key parameters: the bandwidth $h$, the lag order $p$, and the kernel type for $K(\cdot)$ and $L(\cdot)$. We use a lag order based on the Schwarz information criterion (SIC), which is known to select a parsimonious model as compared with other lag-length selection criteria. The SIC criterion helps to overcome the issue of the over-parameterization that typically arises in studies using nonparametric frameworks. For each quantile, we determine the bandwidth parameter $(h)$ by using the leave-one-out least-squares cross validation method. Finally, for $K(\cdot)$ and $L(\cdot)$, we use Gaussian kernels.

Given the evidence in Sadorsky (2006) that a GARCH(1,1) model fits very well with crude oil price volatility, we also decided to check for the robustness of our results in terms of volatility. Hence, we first recover a measure of conditional volatility from a $\operatorname{GARCH}(1,1)$ 
model and then apply the causality-in-quantiles test to this measure of volatility. The basics of $\operatorname{GARCH}(1,1)$ model is as follows:

$$
\begin{gathered}
y_{t}=\mu+\varepsilon_{t}, \\
h_{t}=\omega+\alpha \varepsilon_{t-1}^{2}+\beta h_{t-1},
\end{gathered}
$$

where $y_{t}$ represents the oil returns series and $\varepsilon_{t}$ is the stochastic disturbance term that is assumed to be normally distributed with zero mean. The conditional variance $h_{t}$ depends on the mean volatility level $(\omega)$, the lagged error $\left(\varepsilon_{t-1}^{2}\right)$, and the lagged conditional variance $\left(h_{t-1}\right)$.

\section{Data}

The empirical analysis utilizes monthly data for WTI oil prices and the dummy variables capturing various types of disaster risks over the period of 1918:01 to 2013:12. The start and end dates are governed purely by the availability of data on disaster risks. Oil price data is sourced from the Global Financial Database, with returns computed as the monthly logarithmic change of oil prices multiplied by 100 to convert the returns into percentages. Since WTI oil price data is available from 1859:09, we do not lose the first observation while computing oil returns. Figures 1(a) and 1(b) present the plot of monthly oil returns and the histogram of the series along with the summary statistics, respectively. We observe that the oil return data is skewed to the left with excess kurtosis, resulting in the null of normality under the Jarque-Bera test being overwhelmingly rejected at the highest level of significance. The non-normal distribution, in turn, provides preliminary motivation for relying on a quantiles-based approach for our analysis.

\section{[Insert Figure 1]}

Next we turn our attention to our measure of disaster risks of rare events as obtained from the International Crisis Behavior (ICB) database. ICB database started in 1975 and covers 
comprehensive information regarding 464 international political crises that occurred during the period of 1918 to 2013 at monthly frequency, involving 1,036 crisis actors. Brecher and Wilkenfeld (1997) provide detail discussion on the ICB database, definition and construction of variables. The ICB data has been used in series of books and empirical research papers in many disciplines, including economics, war and political sciences (see for example, Blomberg, et al., (2004); Berkman, et al., (2011, 2017); Huang et al., (2015)) ${ }^{1}$. The underlying motive of the ICB database is to develop a comprehensive list of international political crisis since World War I. As per the ICB database, the breakpoint of a crisis is an event, act or changes characterized by following three conditions: (a) a threat to basic value, (b) excessive chances of involvement in military hostilities, and (c) time pressure for response. ICB database covers a wide range of alternatives to measure the severity of any crisis and, consequently gives us more information to identify the seriousness of the crisis. Note that, to the best of our knowledge, the ICB database is the only available source that compiles data on all major international international political crises, which are likely to cause changes in perceived rare disaster probabilities.

The ICB database distinguishes each crisis on the basis of 81 dimensions including the control variables and crisis mediation, with the possibility of tracing the background of each crisis in detail from the website of ICB database. Further, the ICB database considers those crises only in which the crisis actor is a sovereign entity and has significant participation in any of political conflict. As indicated above, the ICB database covers comprehensive dimensions of each crisis and we take into account many of these dimensions, following Berkman, et al., (2011, 2017), to analyze the impact of international political risk on oil returns and volatility. The foremost variable of our study is total number of crisis (Crisis) in any month $t$. Some crisis can be more severe than others, therefore it is expected that more devastating crisis may have stronger

\footnotetext{
${ }^{1}$ The ICB web site (https://sites.duke.edu/icbdata/) provides an overview of studies that used its data.
} 
effect. Following the Berkman, et al., $(2011,2017)$, we created the following crisis variables: (1) violent break (Violent Break) includes all the crisis that starts with violent act, (2) violent (Violent) crisis includes all the crisis that comprises either serious clashes or full scale war, (3) war (War) includes all the crisis that involves full-scale wars, (4) all crisis that involves grave value threats (Grave Threat), (5) protracted conflicts (Protracted) includes all the crisis with protracted conflict, protracted and crisis outside this conflict, and (6) major power (Major Power) includes the crisis only if at least one superpower or great power is there in both side of conflict. Finally, we also construct a crisis severity index (Crisis Severity Index) that summarizes different aspects of crisis severity into one measure by aggregating the six variables above. Figure 1(c) plots the various rare disaster risks used in this paper.

For all the above crisis variables, we created the dummy variables, which is equal to 1 if the crisis in that group occurs in a specific month, and zero otherwise. The dummy variables are normalized to have a mean of zero and variance of unity, so that we can compare the strength of predictability across the various disaster risks. In other words, we also want to understand, which type of disaster risks carry more information in predicting oil returns and volatility. When the predictors, in our case the dummy variables, have been standardized (i.e., their inherent variability is the same), the higher the test statistic indicating a stronger rejection of the null hypothesis of no-causality, the stronger is the predictability of that particular disaster risk variable. Hence, via this normalization, we not only want to analyze whether the disaster risks can predict oil returns and volatility, but also which disaster risk is comparatively more informative in this regard.

\section{Empirical Findings}

Before we begin our discussion of the findings from the causality-in-quantiles tests, for the sake of completeness and comparability, we first provide the findings from the standard linear Granger causality tests with null hypothesis that a specific rare disaster risk does not affect oil 
returns. As shown in Table 1, the standard linear Granger causality tests yield no evidence of causality that goes from any of the disaster risk variables to oil returns. Therefore, standard linear tests imply no significant causal relationships between rare disaster risks and oil returns.

\section{[Insert Table 1]}

Given the insignificant results obtained from linear causality tests, next we statistically examine the presence of nonlinearity in the relationship between oil returns and the predictor variables representing rare disaster risks. For this purpose, we apply the Brock et al., (1996, BDS) test on the residuals from the return equation used in the linear causality tests involving the rare disaster risk dummies. The results of the BDS test of nonlinearity presented in Table 2 provide strong evidence of rejection of the null hypothesis of i.i.d. residuals at various embedded dimensions $(m)$. Thus, we conclude that there exists nonlinearity in the relationship between oil returns and the rare disaster risk dummies. This evidence also indicates that the findings based on the linear Granger causality test as presented in Table 1 cannot be deemed robust and reliable.

In addition to the BDS test, we also apply the Bai and Perron (2003) tests of multiple structural breaks on the oil return equation used to test linear Granger causality based on the various types of disaster risks. Using the powerful UDmax and WDmax tests, and allowing for a maximum of five breaks with fifteen percent endpoint trimming as well as heterogeneous error distributions across breaks, we detect three breaks (1941:07, 1971:12, and 1986: 04) in all cases. ${ }^{2}$ The presence of these breaks further confirms our earlier findings, based on nonlinearity tests, that the linear model is misspecified.

Given the strong evidence of nonlinearity and regime changes in the relationship between oil returns and the crises dummies, we now turn our attention to the causality-in-

\footnotetext{
${ }^{2}$ Complete details of the Bai and Perron (2003) tests of structural breaks are available upon request from the authors.
} 
quantiles test, which is robust to possible misspecification due to nonlinearity and structural breaks given its nonparametric (i.e. data-driven) structure.

\section{[Insert Table 2]}

Table 3 presents the findings from the causality-in-quantiles tests estimated over the quantile range from 0.10 to 0.90 . Panels A and B present the findings for WTI oil returns and volatility (squared returns) respectively and the null hypothesis is that rare disaster risk dummies (in columns) do not Granger cause oil returns and volatility. Unlike the insignificant findings from linear tests reported in Table 1, we observe in Table 3 that the null is consistently rejected, implying strong evidence of predictability running from all the various disaster risks dummies to both returns and volatility in the oil market. These findings are in line with the evidence for stock market returns in Barro (2006, 2009), Gourio (2008a, b, 2012), Berkman et al. (2011, 2017), Gabaix (2012), among others and suggest that disaster probabilities associated with consumption and/or investment shocks commonly affect stock and oil price processes.

Interestingly however, we see that causality is particularly strong at the lower end of the respective conditional distributions, while the strongest effect on volatility is observed at quantile of 0.10 with the same observed at the quantile of 0.30 in the case of oil return. We also see that this pattern is consistent across the various disaster risk proxies. These findings suggest that, while the predictive power of rare disaster risks over oil market dynamics is statistically significant for the entire conditional distributions of returns and volatility, the causal effect is strongest when the returns and volatility are in the lowest quantile, corresponding to negative oil returns coupled with low return volatility. It can thus be argued that rare disaster risks relate to negative jumps, i.e. large instantaneous changes, in oil prices (implied by lower quantiles), while these jumps are not necessarily associated with high volatility, possibly due to lower trading activity or other factors driving investor behaviour. The high degree of nonlinearity in the relationship between time varying disaster risks and oil return dynamics reported in Table 
3 is in line with the model for an endowment economy proposed by Weitzman (2007) based on non-normal consumption growth rate such that the conditional distribution of consumption growth becomes highly non-normal when a disaster is relatively likely. To that end, the findings imply that the effect of disaster risks on oil return dynamics is primarily channeled via aggregate consumption shocks in the economy.

Furthermore, the high degree of causality particularly at the lower end of the conditional distributions for oil return and volatility supports Wachter (2013)'s mixed jump-diffusion process for consumption growth in which disasters are captured by a Poisson process, which allows for large instantaneous changes, i.e. jumps, in aggregate consumption. Maheu et al. (2013) define jumps as large changes in daily returns. Similarly, Wachter (2013) models jumps as large instantaneous changes in the price process and shows that excess stock returns are partially driven by a jump component that is due to the time variation in disaster risks. Recently, Guo et al. (2016) decompose the jump component of realized stock market volatility to negative (bad) and positive (good) jumps and show that jump risk has asymmetric effects on the conditional stock market excess returns. Given that our focus is oil returns and volatility, we refrain from labelling positive and negative jumps in the oil price process as good or bad jumps; however, capture this asymmetry via the quantile specification in our tests. Nevertheless, our findings point to an asymmetry in the effect of time varying disasters risks on jumps in oil returns and volatility. Given the finding by Larsson and Nossman (2011) that jumps are an essential factor needed to correctly capture the time series properties of oil prices, our findings have significant implications for hedging and the pricing of oil derivatives.

\section{[Insert Table 3]}

In order to further confirm the causal effects of rare disaster risks on oil return volatility, we present in Table 4, the findings for the tests of causality from the disaster risk dummies to 
the conditional volatility estimates obtained from the $\operatorname{GARCH}(1,1)$ model discussed earlier. Again, barring three individual exceptions (i.e. the quantile of 0.60 and $0.50-0.60$ for 'War' and 'Grave Threat', respectively), we observe strong evidence of predictability for the GARCH-based volatility measures emanating from the rare disaster risk dummies. As observed for squared returns in Table 3, we see again that the dummy capturing all possible crises tends to be the strongest predictor, consistently at all quantiles. However, unlike the findings reported in Table 3, we see that the causal effects are not necessarily the strongest at lower quantiles of the respective conditional distributions. It must, however, be noted that Balcilar et al. (2016b) suggests that one should rely on the results obtained under squared returns as a measure of volatility, rather than a model-based measure of the same, since the analysis for the squared returns follows directly from the $k$-th order test of nonparametric causality-in-quantiles.

\section{[Insert Table 4]}

As explained earlier in the data description, the findings reported in Tables 3 and 4 utilize dummy variables that represent various definitions of rare disaster risks. In addition to these dummy variables, the ICB dataset also provides the monthly count for the risk variables under the various categories as well as information on their start and end dates, i.e. the span of the crisis. Therefore, as a robustness check, we repeat our analysis using the monthly counts for various risk categories instead. The findings in Table 5 further confirm our previous results in Table 3 that are based on the crisis dummy variables, indicating strong evidence of predictability for both oil returns and volatility over the entirety of the respective conditional distributions. The causal effects from rare disaster risks are found to be significant irrespective of what phase the month is classified as, i.e. start, end and duration of the crisis. Furthermore, we observe that the pattern of the strength of the causal relationship with the count data is similar to that observed when the dummies are used as predictors, along with the importance of the predictive ability of the predictor variable capturing all the crises. In short, our findings 
yield significant evidence of a causal relationship between rare disaster risks and oil return and volatility with the effect being particularly strong at low quantiles of the conditional distribution representing periods of negative oil returns.

\section{[Insert Table 5]}

As additional robustness checks, we also used the news-based measures of implied volatility (NVIX) as developed by Manela and Moreira $(2017)^{3}$ and geopolitical risks (GPRs) of Caldara and Iacoviello $(2017)^{4}$, as possible alternative measures of rare disaster risks. The NVIX and the GPRs indexes also contain information about possible disaster risks (see, Footnotes 3 and 4 respectively in this regard) and hence, serves as an alternative to the ICB database. The NVIX and the GPRs are used to check for the robustness of our results obtained using the ICB database, which in turn, is popularly used for capturing rare disaster risks in the associated literature. Even though the NVIX and GPR indexes are based on news on various types of risks in the US newspapers, they do cover global disaster news as well and hence, is likely to be important for a global market like oil. Also note, since we are analyzing the WTI market, US-based risks should also matter, besides global disaster risks, which the ICB aims to capture.

\footnotetext{
${ }^{3}$ The news dataset to construct the NVIX includes the title and abstract of all front-page articles of the Wall Street Journal. Manela and Moreira (2017) focus on front-page titles and abstracts in order to ensure feasibility of data collection, and also because these are manually edited and corrected following optical character recognition, which in turn, improves their earlier sample reliability. The NVIX data is found to peak during stock market crashes, times of policy-related uncertainty, world wars, and financial crises. The reader is referred to Manela and Moreira (2017) for further details, who also discuss how they decompose the aggregate NVIX into its components. The NVIX components capture uncertainty stemming from (with the words searched for in brackets) government policy (tax, money, rates, government, plan), intermediation (banks, financial, business, bank, credit), natural disaster (fire, storm, aids, happening, shock), securities markets/stock markets (stock, market, stocks, industry, markets), and wars (war, military, action,world war, violence). There is also available data for an "unclassified" component (U.S., special, Washington, treasury, gold). The data is available for download from: http://apps.olin.wustl.edu/faculty/manela/data.html.

${ }^{4}$ Caladara and Iacoviello (2017) construct a long-span monthly GPR index dating back to 1899, based on terms related to geopolitical risks covered in three newspapers namely, the New York Times, Chicago Tribune, and the Washington Post. The phrases considered for constructing the index are: "geopolitical risk(s)", "geopolitical concern(s)", "geopolitical tension(s)", "geopolitical uncertainty(ies)", "N/3" (“crisis" OR "uncertain")), "war risk(s)" (OR "risk(s) of war"), state of war" OR "declaration of war", "war" OR "military" and "military threat(s)", "terrorist threat(s)", "terrorist act(s)", "Middle East AND tensions". The data can be downloaded from: https://www2.bc.edu/matteo-iacoviello/gpr.htm.
} 
As can be seen from the results reported in Tables A1 (covering the period of 1889:07 to 2016:03) and A2 (over the period of 1899:01 to 2017:06) in the Appendix of the paper, there is strong evidence of predictability for oil returns and volatility (squared returns) due to aggregate measures of NVIX and GPR and their respective components, (i.e., uncertainty associated with government policy, intermediation, natural disaster, securities markets, war and unclassified events under the NVIX, and GPR acts and GPR threats under GPRs) respectively. Note that, the pattern associated with strength of causality is similar to those reported for the rare-disaster risks.

\section{Conclusion}

This paper extends the literature on the effect of rare disaster risks on financial market returns to the commodity market, in particular crude oil. Unlike other applications to stock and bond returns, we provide a novel perspective to the predictive ability of rare disaster risks for returns and volatility in the WTI oil market using a $k$-th order nonparametric quantile-based methodology that allows to capture nonlinear causal effects. Using monthly data on oil returns and various disaster risk proxies for the period of 1918:01 to 2013:12, we first show that standard linear causality tests yield insignificant results in terms of the predictive power of rare disasters over WTI returns. However, additional tests reveal strong evidence of nonlinearity and regime changes in the relationship between oil returns and the rare disaster risk proxies, indicating that the linear Granger causality test is misspecified, thus the results cannot be relied on.

Applying the nonparametric quantile-causality test, which is robust to misspecification due to nonlinearity and structural breaks, we show that rare disaster risk proxies strongly predict both returns and volatility for oil, with stronger causal effects observed at the lower ends of their respective conditional distributions. We argue that rare disaster risks potentially 
contribute to jump risk in oil returns (more significantly to negative jumps in this case) that has been documented in several previous studies (Larsson and Nossman, 2011; Christoffersen et al., 2016; and Baum and Zerilli, 2016). The findings also suggest that the effect of oil price shocks on stock market return dynamics could partially be channelled via the time-variation in disaster risk probabilities that commonly affects both the stock and oil price processes.

From the perspective of an academic, our results tend to suggest that the WTI market cannot be categorized as weakly efficient. Furthermore, the finding of strong asymmetric causal effects on oil returns, particularly at low quantiles, suggests that models of jump risk as well as jump diffusion models with stochastic volatility for crude oil dynamics can be improved by integrating proxies of rare disaster risks. From a pricing perspective, following the evidence by Christoffersen et al. (2016) that jumps command a premium in crude oil derivatives prices, our findings suggest that rare disaster risk proxies can be integrated in pricing models in order to improve forecasting models for crude oil prices.

From a policy making perspective, considering the suggestion by Barro, $(2006,2009)$, Gourio (2012) and Wachter (2013) that if uncertainty regarding the probability and size of disasters leads to a great deal of uncertainty in terms of investment growth or consumption patterns, the strong evidence of a rare disaster effect on crude oil return and volatility suggests that policy makers who are worried about the potential negative impact of oil price fluctuations on the real economy should build rare disaster risk proxies into their forecasting models. Given that time varying disaster risks affect risk and return dynamics in both the stock and oil market, one can argue that disaster risks represent a component of uncertainty that relates to the real economy, either via investment or aggregate consumption patterns. It would thus make sense to supplement forecasting models for the real economy with proxies of rare disaster risks. This is particularly important given the evidence in the paper that causal effects are especially strong at the lower quantiles of the conditional distribution of oil returns. However, it must be noted 
that nonlinearity and possible structural breaks must be taken into account in order to correctly capture the effect of rare disaster risks on oil returns as our results show that using a linear model is likely to lead to incorrect inferences.

Overall, our results highlight the importance of testing for nonlinearity and structural changes, and if it exists, use a data-driven nonlinear approach to analyze causal relationships. The results also highlight the importance of having a nonlinear pricing framework that integrates disaster risks in the pricing model, perhaps via models that utilize higher order moments. As part of future research, it would be interesting to extend our analysis to a forecasting exercise, as in Bonaccolto et al. (2018), since in-sample predictability does not guarantee the same over- and out-of-sample. 


\section{References}

Alsalman, Z., Herrera, A. M. 2015. Oil price shocks and the U.S. stock market: Do sign and size matter? The Energy Journal, 36(3), 171-188.

Apergis, N., Miller, S., 2009. Do structural oil market shocks affect stock prices? Energy Econ. $31,569-575$.

Arouri, M.E.H., Rault, C., 2011. On the influence of oil prices on stock markets: evidence from panel analysis in GCC countries. Int. J. Financ. Econ. 3, 242-253.

Bai, J., Perron, P., 2003. Computation and analysis of multiple structural change models. Journal of Applied Econometrics, 18, 1-22.

Balcilar, M., Bekiros, S., Gupta, R., 2016a. The role of news-based uncertainty indices in predicting oil markets: a hybrid nonparametric quantile causality method. Empirical Economics, doi: 10.1007/s00181-016-1150-0.

Balcilar, M., Gupta, R., Pierdzioch, C., and Wohar, M.E. 2016b. Terror Attacks and StockMarket Fluctuations: Evidence Based on a Nonparametric Causality-in-Quantiles Test for the G7 Countries. European Journal of Finance, http://dx.doi.org/10.1080/1351847X.2016.1239586.

Barro, R. J., 2006. Rare Disasters and Asset Markets in the Twentieth Century. Quarterly Journal of Economics, 121, 823-866.

Barro, R.J. 2009. Rare Disasters, Asset Prices, and Welfare Costs. American Economic Review, 99(1), 243-264.

Barro, R.J., and Jin, T. 2011. On the Size Distribution of Macroeconomic Disasters. Econometrica, 79(5), 1567-1589.

Barro, R.J., and Ursúa, J.F. 2008. Macroeconomic Crises since 1870. Brookings Papers on Economic Activity, 38(1), 255-350.

Barro, R.J., and Ursúa, J.F. 2009. Stock-Market Crashes and Depressions. National Bureau of Economic Research (NBER) Working Paper 14760.

Barro, R.J., and Ursúa, J.F. 2012. Rare Macroeconomic Disasters. Annual Review of Economics, 4, 10.1-10.17.

Basher, S. A., Haug, A. A., Sadorsky, P. 2012. Oil prices, exchange rates and emerging stock markets. Energy Economics, 34(1), 227-240.

Basher, S. A., Sadorsky, P. 2006. Oil price risk and emerging stock markets. Global Finance Journal, 17, 224-251. 
Baum, C. F., and Zerilli, P. 2016. Jumps and stochastic volatility in crude oil futures prices using conditional moments of integrated volatility. Energy Economics 53, 175-181.

Berkman, H., Jacobsen, B. and Lee, J.B. 2011.Time-varying rare disaster risk and stock returns, Journal of Financial Economics, 101, 313-332.

Berkman, H., Jacobsen, B. and Lee, J.B. 2017. Rare disaster risk and the expected equity risk premium, Accounting and Finance, 57(2), 351-372.

Bernanke, B. 2016. The relationship between stocks and oil prices. Brookings. Available for download at: https://www.brookings.edu/blog/ben-bernanke/2016/02/19/therelationship-between-stocks-and-oil-prices/.

Blomberg, S.B., Hess, G.D. and Orphanides, A., 2004. The macroeconomic consequences of terrorism. Journal of monetary economics, 51(5), 1007-1032.

Bonaccolto, G., Caporin, M., Gupta, R., 2018. The dynamic impact of uncertainty in causing and forecasting the distribution of oil returns and risk. Studies in Nonlinear Dynamics and Econometrics 507 (1), 446-469.

Brecher, M. and Wilkenfeld, J., 1997. A study of crisis. University of Michigan Press.Brock, W., Dechert, D., Scheinkman, J., and LeBaron, B. (1996). A test for independence based on the correlation dimension. Econometric Reviews, 15 197-235.

Caldara, D., and Iacoviello, M., 2017. Measuring Geopolitical Risk. Working Paper, Board of Governors of the Federal Reserve Board.

Chen, S. 2010. Do higher oil prices push the stock market into bear territory? Energy Economics, 32(2), 490-495.

Christoffersen, P., Jacobs, K. and Li, B. 2016. Dynamic Jump Intensities and Risk Premiums in Crude Oil Futures and Options Markets. The Journal of Derivatives 24 (Winter 2016), No. 2, 8-30

Cunado, J., De Gracia, F. P. 2014. Oil price shocks and stock market returns: Evidence for some European countries. Energy Economics, 42, 365-377.

Diks, C. G. H. and Panchenko, V. 2005. A note on the Hiemstra-Jones test for Granger noncausality. Studies in Nonlinear Dynamics and Econometrics, 9(2), 1-7.

Diks, C. G. H. and Panchenko, V. 2006. A new statistic and practical guidelines for nonparametric Granger causality testing. Journal of Economic Dynamics and Control, 30(9-10), 1647-1669.

Driesprong, G., Jacobsen, B., Maat, B., 2008. Striking oil: Another puzzle? J. Financ. Econ. $89,307-327$. 
Elder, J., and Serletis, A. 2010. Oil Price Uncertainty. Journal of Money, Credit and Banking, 42(6), 1137-1159.

Farhi, E., X. Gabaix, 2014, Rare Disasters and Exchange Rates, Quarterly Journal of Economics, 131(1), 1-52.

Gabaix, X., 2012. Variable Rare Disasters: An Exactly Solved Framework for Ten Puzzles in Macro-Finance, Quarterly Journal of Economics 127(2), 645-700.

Gourio, F., 2008a. Time-series predictability in the disaster model. Finance Research Letters, 5,191-203.

Gourio F., 2008b. Disasters and recoveries. The American Economic Review, 98, 68-73.

Gourio, F., 2012. Disaster Risk and Business Cycles. The American Economic Review, 102(6), 2734-2766.

Guo, H., Wang, K., Zhou, H. 2016. Good Jumps, Bad Jumps, and Conditional Equity Premium. Working Paper (December 2016). Working paper.

Hamilton, J.D., 1983. Oil and the macroeconomy since World War II. Journal of Political Economy 91(2), 228-248.

Hamilton, J.D., 2008. Oil and the macroeconomy. In Durlauf, S., Blume, L. (eds.), New Palgrave Dictionary of Economics, 2nd edition, Palgrave McMillan Ltd.

Hamilton, J.D., 2009. Causes and consequences of the oil shock of 2007-08. Brookings Papers on Economic Activity 40(1), 215-283.

Hamilton, J.D., 2013. Historical oil shocks. In Parker, R.E., Whaples, R. (eds.), Routledge Handbook of Major Events in Economic History, New York: Routledge Taylor and Francis Group, 239-265.

Hiemstra, C. and Jones, J.D. 1994. Testing for linear and nonlinear Granger causality in the stock price-volume relation. Journal of Finance, 49(5), 1639-1664.

Huang, T., Wu, F., Yu, J. and Zhang, B., 2015. International political risk and government bond pricing. Journal of Banking \& Finance, 55, 393-405.

Huang, X., Tauchen, G. 2005. The Relative Contribution of Jumps to Total Price Variance. Journal of Financial Econometrics, 2005, Vol. 3, No. 4, 456-499.

Jimenez-Rodriguez, R., Sanchez, M., 2005. Oil price shocks and real GDP growth, empirical evidence for some OECD countries. Appl. Econ. 37, 201-228.

Jeong, K., Härdle, W.K., Song, S., 2012. A consistent nonparametric test for causality in quantile. Econometric Theory, 28(4), 861-887.

Jo, S., 2014. The effects of oil price uncertainty on global real economic activity. J. Money Credit Bank. 46, 1113-1135. 
Jones, C.M., Kaul, G., 1996. Oil and the stock markets. J. Finance 51, 463-491.

Kilian, L., Park, C., 2009. The impact of oil price shocks on the US stock market. Int. Econ. Rev. 50, 1267-1287.

Larsson, K., Nossman, M., 2011. Jumps and stochastic volatility in oil prices: Time series evidence. Energy Economics 33 (3), 504-514.

Maheu, J., and McCurdy, T., 2004, News arrival, jump dynamics and volatility components for individual stock returns. Journal of Finance 59, 755-793.

Maheu, J. M., McCurdy, T.H., Zhao, X. 2013. Do jumps contribute to the dynamics of the equity premium? Journal of Financial Economics 110, 457-477.

Manela, A., and Moreira, A. 2017. News Implied Volatility and Disaster Concerns, Journal of Financial Economics, 123(1), 137-162.

Mensi, W., Hammoudeh, S., Yoon, S.-M., 2014. How do OPEC news and structural breaks impact returns and volatility in crude oil markets? Further evidence from a long memory process. Energy Economics 42, 343-354.

Miller, J.I., Ratti, R.A., 2009. Crude oil and stock markets: Stability, instability and bubbles. Energy Econ. 31, 559-568.

Nakamura, E., Steinsson, J., Barro, R.J., and Ursúa, J.F. 2013. Crises and recoveries in an empirical model of consumption disasters. American Economic Journal: Macroeconomics, 5(3), 35-74.

Nandha, M., Faff, R., 2008. 'Does oil move equity prices? A global view'. Energy Econ. 30, 986-997.

Nishiyama, Y., Hitomi, K., Kawasaki, Y., Jeong, K., 2011. A consistent nonparametric test for nonlinear causality - Specification in time series regression. Journal of Econometrics, 165, $112-127$.

Sadorsky, P., 1999. Oil price shocks and stock market activity. Energy Econ. 21, 449-469.

Sadorsky, P., 2006. Modeling and forecasting petroleum futures volatility. Energy Economics 28(4), 467-488.

Stock, J.H. and Watson, M.W. 2003. Forecasting Output and Inflation: The Role of Asset Prices. Journal of Economic Literature 41, 788-829.

Wachter, J., 2013, Can time-varying risk of rare disasters explain aggregate stock market volatility? Journal of Finance, 68 (3), 987-1035.

Weitzman, M. L., 2007, Subjective expectations and asset-return puzzles, American Economic Review 97, 1102-1130. 
Zhou, H., J. Wright. 2009. Bond Risk Premia and Realized Jump Risk. Journal of Banking and Finance 33, 2333-2345.

Zhou, H., Zhu, J. Q. 2012. An empirical examination of jump risk in asset pricing and volatility forecasting in China's equity and bond markets. Pacific-Basin Finance Journal 20, 857-880. 
Figure 1(a). Monthly Oil Returns

\section{OIL RETURNS}

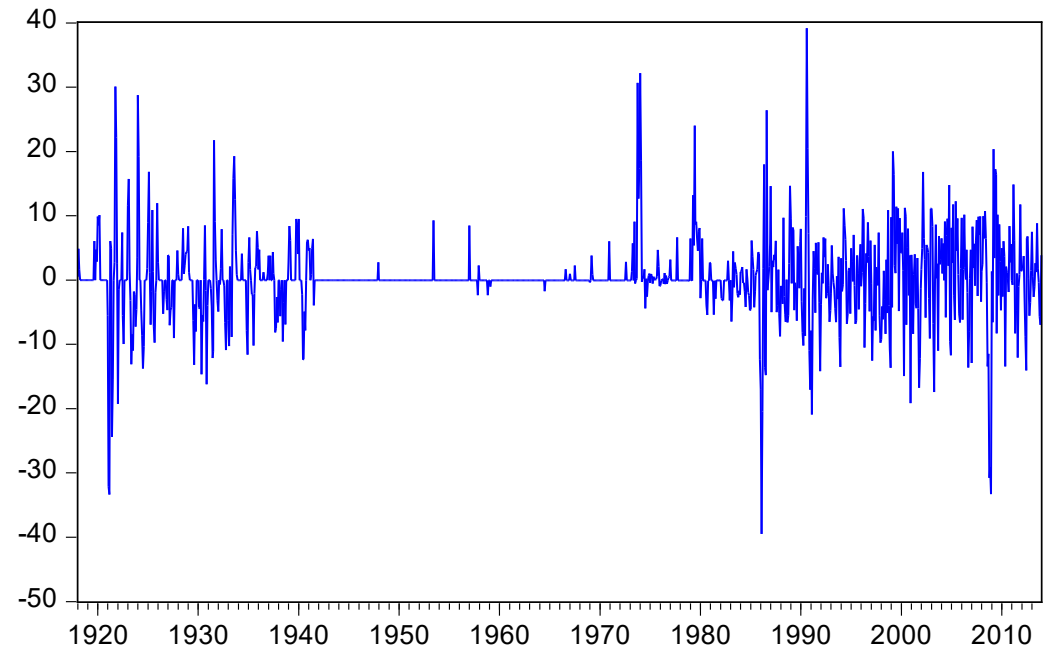

Figure 1(b). Histogram and Summary Statistics for Monthly Oil Returns

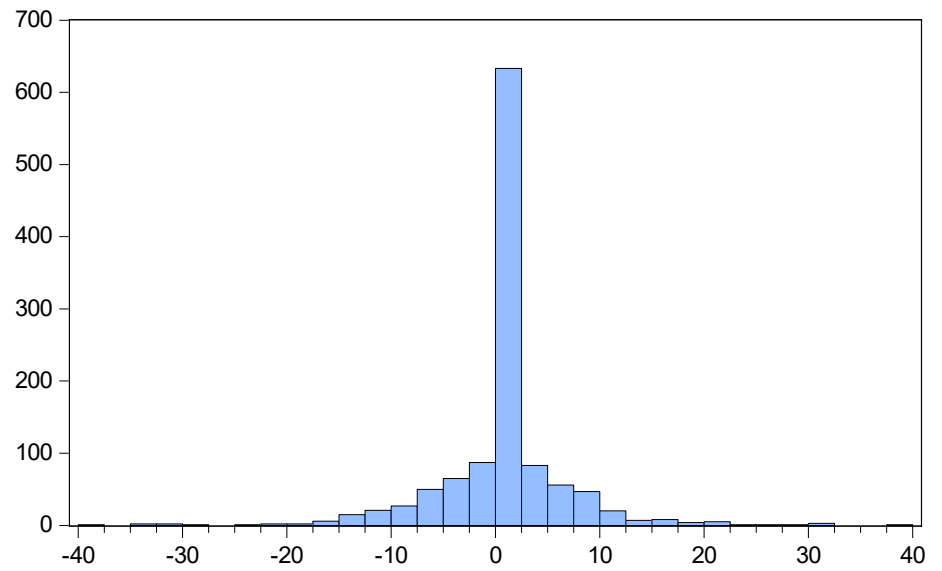

Series: OIL RETURNS Sample 1918M01 2013M12 Observations 1152

Mean $\quad 0.283401$

Median $\quad 0.000000$

Maximum $\quad 39.21886$

Minimum $\quad-39.41901$

Std. Dev. $\quad 6.207000$

Skewness $\quad-0.076555$

Kurtosis $\quad 11.63114$

Jarque-Bera $\quad 3576.961$

Probability $\quad 0.000000$ 
Figure 1(c). Rare Disaster Risks
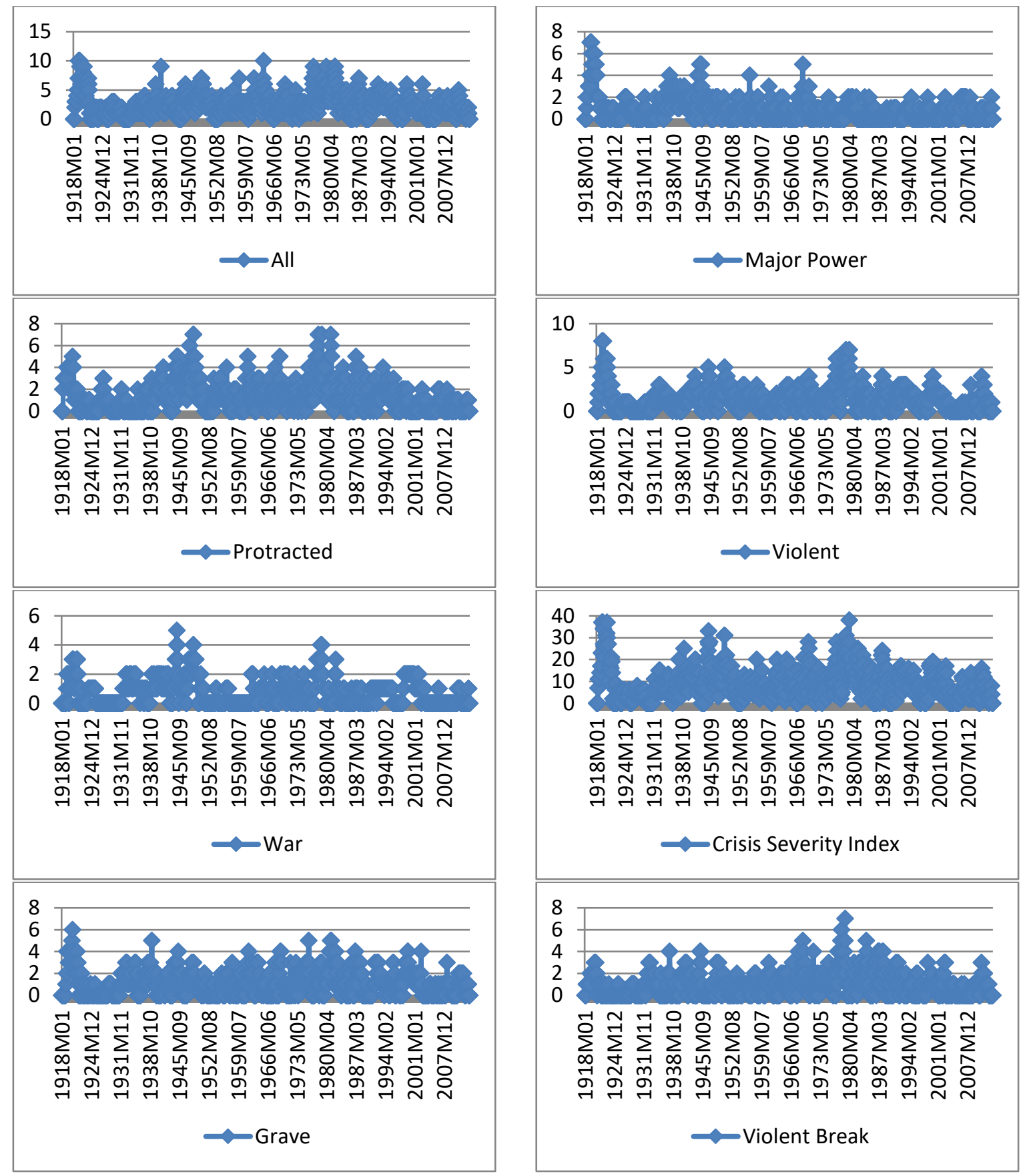

Note: Violent Break includes all the crisis that starts with violent act; Violent crisis includes all the crisis that comprises either serious clashes or full scale war; War includes all the crisis that involves full-scale wars; Grave Threat involves all crisis that involves grave value threats; Protracted includes all the crisis with protracted conflict, protracted and crisis outside this conflict; Major Power includes the crisis only if at least one superpower or great power is there in both side of conflict; Crisis Severity Index summarizes different aspects of crisis severity into one measure by aggregating the six variables above; All corresponds to the sum of the numbers involved in the six types of crises, i.e., All Crises. 
Table 1. Linear Granger Causality Test for WTI Returns.

\begin{tabular}{lll}
\hline Predictor Variable & $\boldsymbol{F}$-stat & $\boldsymbol{p}$-value \\
\hline All & 0.248 & 0.619 \\
Violent & 0.257 & 0.612 \\
War & 0.393 & 0.531 \\
Violent Break & 0.657 & 0.418 \\
Protracted & 0.187 & 0.665 \\
Major Power & 0.130 & 0.719 \\
Grave Threat & 3.681 & 0.055 \\
Crisis Severity Index & 1.375 & 0.241 \\
\hline
\end{tabular}

Note: The null hypothesis is that a specific rare disaster-risk does not affect WTI returns.

Table 2. Brock et al. (1996) (BDS) Test of Nonlinearity.

Predictor Variable

Dimension

\begin{tabular}{|c|c|c|c|c|c|}
\hline & 2 & 3 & 4 & 5 & 6 \\
\hline All & $11.930 * * *$ & $14.668 * * *$ & $16.648 * * *$ & $18.965 * * *$ & $22.139 * * *$ \\
\hline Violent & $11.800 * * *$ & $14.612 * * *$ & $16.711 * * *$ & $19.048 * * *$ & $22.215 * * *$ \\
\hline War & $11.955 * * *$ & $14.705^{* * *}$ & $16.867 * * *$ & $19.189 * * *$ & $22.293 * * *$ \\
\hline Violent Break & $11.968 * * *$ & $14.667 * * *$ & $16.744 * * *$ & $19.056^{* * *}$ & $22.144 * * *$ \\
\hline Protracted & $11.861 * * *$ & $14.694 * * *$ & $16.813^{* * *}$ & $19.114 * * *$ & $22.287 * * *$ \\
\hline Major Power & $11.599 * * *$ & $14.351 * * *$ & $16.516^{* * *}$ & $18.849 * * *$ & $21.986 * * *$ \\
\hline Grave Threat & $12.159 * * *$ & $14.753 * * *$ & $16.772 * * *$ & $19.101 * * *$ & $22.181 * * *$ \\
\hline Crisis Severity Index & $11.918^{* * *}$ & $14.654 * * *$ & $16.639 * * *$ & $18.967 * * *$ & $22.053 * * *$ \\
\hline
\end{tabular}

Notes: The table reports the $z$-statistic of the BDS test corresponding to the null of i.i.d. residuals, with the test applied to the residuals recovered from the oil returns equation used to test linear Granger causality. *** indicates rejection of the null hypothesis at the 1 per cent level of significance. 
Table 3. Causality-in-Quantiles Test for WTI Returns and Volatility (Squared Returns).

\begin{tabular}{|c|c|c|c|c|c|c|c|c|}
\hline & \multicolumn{8}{|c|}{ Panel A: Returns } \\
\hline Quantile & All & Violent & War & $\begin{array}{l}\text { Violent } \\
\text { Break }\end{array}$ & Protracted & Major Power & $\begin{array}{l}\text { Grave } \\
\text { Threat }\end{array}$ & $\begin{array}{c}\text { Crisis Severity } \\
\text { Index }\end{array}$ \\
\hline 0.1 & $7.2167 * * *$ & $5.9849 * * *$ & $5.4766 * * *$ & $5.7708 * * *$ & $7.7755 * * *$ & $6.1204 * * *$ & $5.4457 * * *$ & $6.9386 * * *$ \\
\hline 0.2 & $19.5019 * * *$ & $17.1903 * * *$ & $14.4331 * * *$ & $15.7936^{* * *}$ & $19.2176^{* * *}$ & $14.8955^{* * *}$ & $14.3119 * * *$ & $18.6151^{* * *}$ \\
\hline 0.3 & $279.2003 * * *$ & $238.5665 * * *$ & $208.7500 * * *$ & $213.8353 * * *$ & $243.1471 * * *$ & $210.4238 * * *$ & $217.6757 * * *$ & $275.6247 * * *$ \\
\hline 0.4 & $173.4119 * * *$ & $149.0373 * * *$ & $129.4330 * * *$ & $132.5578 * * *$ & $152.2913 * * *$ & $130.6833 * * *$ & $135.0629 * * *$ & $171.4894 * * *$ \\
\hline 0.6 & $53.6906 * * *$ & $47.1067 * * *$ & $40.0197 * * *$ & $40.8640 * * *$ & $48.9061 * * *$ & $40.7026^{* * *}$ & $41.6172 * * *$ & $53.5231 * * *$ \\
\hline 0.7 & $29.0606 * * *$ & $25.8022 * * *$ & $21.5436 * * *$ & $22.6722 * * *$ & $27.0010 * * *$ & $22.1472 * * *$ & $22.6865 * * *$ & $29.3225 * * *$ \\
\hline 0.8 & $16.1053 * * *$ & $14.5167 * * *$ & $11.7761 * * *$ & $12.5703 * * *$ & $14.7595 * * *$ & $12.0140 * * *$ & $12.2454 * * *$ & $16.1916^{* * *}$ \\
\hline \multirow[t]{2}{*}{0.9} & $5.7863 * * *$ & $5.2800 * * *$ & $4.1152 * * *$ & $4.6741 * * *$ & $5.3899 * * *$ & $4.4439 * * *$ & $4.3940 * * *$ & $6.1935 * * *$ \\
\hline & \multicolumn{8}{|c|}{ Panel B: Volatility (Square Returns) } \\
\hline Quantile & All & Violent & War & $\begin{array}{l}\text { Violent } \\
\text { Break }\end{array}$ & Protracted & Major Power & $\begin{array}{l}\text { Grave } \\
\text { Threat }\end{array}$ & $\begin{array}{c}\text { Crisis Severity } \\
\text { Index }\end{array}$ \\
\hline 0.1 & $631.1909 * * *$ & $539.6444 * * *$ & $466.3895 * * *$ & $481.3387 * * *$ & $556.0854 * * *$ & $473.1998 * * *$ & $478.6326 * * *$ & $621.0273 * * *$ \\
\hline 0.2 & $349.2724 * * *$ & $299.6418 * * *$ & $257.6132 * * *$ & $265.9864 * * *$ & $309.8051 * * *$ & $261.8596 * * *$ & $263.9420 * * *$ & $344.0051 * * *$ \\
\hline 0.3 & $213.4727 * * *$ & $184.0816 * * *$ & $157.0160 * * *$ & $162.3453 * * *$ & $191.2074 * * *$ & $160.1548 * * *$ & $160.6011 * * *$ & $210.5786 * * *$ \\
\hline 0.4 & $128.8988 * * *$ & $111.9472 * * *$ & $94.5197 * * *$ & $97.7984 * * *$ & $117.1264 * * *$ & $96.8104^{* * *}$ & $96.3064 * * *$ & $127.4379 * * *$ \\
\hline 0.5 & $72.3227 * * *$ & $63.5989 * * *$ & $52.7842 * * *$ & $54.7027 * * *$ & $67.3249 * * *$ & $54.5118 * * *$ & $53.4791 * * *$ & $71.7795 * * *$ \\
\hline 0.6 & $34.3296 * * *$ & $30.9207 * * *$ & $24.9338 * * *$ & $25.8610 * * *$ & $33.5145^{* * *}$ & $26.2367 * * *$ & $24.9599 * * *$ & $34.3277 * * *$ \\
\hline 0.7 & $24.7935 * * *$ & $23.1330 * * *$ & $18.1842 * * *$ & $19.5660 * * *$ & $25.7776 * * *$ & $18.3414 * * *$ & $18.3407 * * *$ & $24.8117^{* * *}$ \\
\hline 0.8 & $14.1292 * * *$ & $13.3836 * * *$ & $10.1449 * * *$ & $11.2249 * * *$ & $14.9017 * * *$ & $10.3858 * * *$ & $10.2733 * * *$ & $14.1644 * * *$ \\
\hline 0.9 & $6.0922 * * *$ & $5.5954 * * *$ & $4.2872 * * *$ & $4.9774 * * *$ & $6.3375 * * *$ & $4.5782 * * *$ & $4.3707 * * *$ & $6.4134 * * *$ \\
\hline
\end{tabular}

Note: Entries correspond to the quantile causality test statistic for the null hypothesis that various disaster risk dummies (in separate

columns) does not Granger cause oil returns and volatility; ***, **, * indicates rejection of null of no-causality at 1,5 , and 10 percent

levels respectively. 
Table 4. Causality-in-Quantiles Test for GARCH(1,1)-based WTI Volatility Estimates.

\begin{tabular}{|c|c|c|c|c|c|c|c|c|}
\hline \multirow[b]{2}{*}{ Quantile } & \multicolumn{8}{|c|}{ Volatility (GARCH $(1,1)$ Model-Based) } \\
\hline & All & Violent & War & $\begin{array}{l}\text { Violent } \\
\text { Break }\end{array}$ & Protracted & $\begin{array}{l}\text { Major } \\
\text { Power }\end{array}$ & $\begin{array}{l}\text { Grave } \\
\text { Threat }\end{array}$ & $\begin{array}{c}\text { Crisis Severity } \\
\text { Index }\end{array}$ \\
\hline 0.1 & $5.2345 * * *$ & $4.3334 * * *$ & $4.0593 * * *$ & $4.2123 * * *$ & $4.7818 * * *$ & $4.3514 * * *$ & $4.1827 * * *$ & $5.1350 * * *$ \\
\hline 0.2 & $8.4311 * * *$ & $6.5370 * * *$ & $6.2099 * * *$ & $6.4308 * * *$ & $6.4431 * * *$ & $6.4207 * * *$ & $7.2190 * * *$ & $8.2695 * * *$ \\
\hline 0.3 & $5.0632 * * *$ & $4.4685 * * *$ & $4.2592 * * *$ & $4.2502 * * *$ & $3.9384 * * *$ & $4.0504 * * *$ & $4.8567 * * *$ & $5.0498 * * *$ \\
\hline 0.4 & $3.6314^{* * *}$ & $3.7429 * * *$ & $4.5695 * * *$ & $4.1455^{* * *}$ & $4.3216 * * *$ & $4.6548 * * *$ & $2.7718 * * *$ & $3.8262 * * *$ \\
\hline 0.5 & $2.5816^{* * *}$ & $2.6178 * * *$ & $4.0084 * * *$ & $5.3662 * * *$ & $4.1678 * * *$ & $6.0842 * * *$ & $1.7399 *$ & $2.8590 * * *$ \\
\hline 0.6 & $2.2468 * *$ & $2.0950 * *$ & 1.5835 & $4.7149 * * *$ & $2.4144 * *$ & $2.1570 * *$ & $1.9013^{*}$ & $1.9956^{* *}$ \\
\hline 0.7 & $5.7037 * * *$ & $6.1404 * * *$ & $3.9138 * * *$ & $9.6417 * * *$ & $8.8365^{* * *}$ & $7.0366 * * *$ & $4.3595 * * *$ & $5.2521 * * *$ \\
\hline 0.8 & $6.3596 * * *$ & $6.6967 * * *$ & $5.2354 * * *$ & $5.1396 * * *$ & $6.6526^{* * *}$ & $6.1611 * * *$ & $5.0586 * * *$ & $6.0322 * * *$ \\
\hline 0.9 & $4.6533 * * *$ & $4.0788 * * *$ & $3.4723 * * *$ & $3.4463 * * *$ & $4.2418 * * *$ & $3.6229 * * *$ & $3.5172 * * *$ & $4.4707 * * *$ \\
\hline
\end{tabular}

Note: Entries correspond to the quantile causality test statistic for the null hypothesis that various disaster risk dummies (in separate columns) does not Granger cause GARCH-based oil volatility; $* * *, * * * *$ indicates rejection of null of no-causality at 1,5 , and 10 percent levels respectively. 
Table 5. Causality-in-Quantiles Test for WTI Returns and Volatility Based on the Monthly Counts of Rare Disaster Risks over Different Phases.

\begin{tabular}{|c|c|c|c|c|c|c|c|c|c|c|c|}
\hline & & & \multicolumn{9}{|c|}{ Panel A: Returns } \\
\hline & & & \multicolumn{9}{|c|}{ Quantile } \\
\hline \multirow{16}{*}{$\begin{array}{l}\text { Predictor } \\
\text { Variable }\end{array}$} & & & 0.1 & 0.2 & 0.3 & 0.4 & 0.5 & 0.6 & 0.7 & 0.8 & 0.9 \\
\hline & \multirow{3}{*}{ All } & Start & $5.17 * * *$ & $12.97 * * *$ & $\begin{array}{c}206.52^{* *} \\
*\end{array}$ & $\begin{array}{c}127.35^{* *} \\
*\end{array}$ & $\begin{array}{c}74.60^{* *} \\
*\end{array}$ & $\begin{array}{c}38.54 * * \\
*\end{array}$ & $\begin{array}{c}20.37^{* *} \\
*\end{array}$ & $\begin{array}{c}12.29^{* *} \\
*\end{array}$ & $\begin{array}{c}4.14^{* *} \\
*\end{array}$ \\
\hline & & During & $371 * * *$ & $965 * * *$ & $\begin{array}{c}142.82 * * \\
*\end{array}$ & $88.94 * * *$ & $\begin{array}{c}52.90^{* *} \\
*\end{array}$ & $\begin{array}{c}28.30^{* *} \\
*\end{array}$ & $\begin{array}{c}15.63 * * \\
*\end{array}$ & $938 * * *$ & $\begin{array}{c}3.47 * * \\
*\end{array}$ \\
\hline & & End & $5.16^{* * *}$ & $13.84 * * *$ & $\begin{array}{c}210.58^{* *} \\
*\end{array}$ & $\begin{array}{c}130.65^{* *} \\
*\end{array}$ & $\begin{array}{c}77.07^{* *} \\
*\end{array}$ & $\begin{array}{c}40.43^{* *} \\
*\end{array}$ & $\begin{array}{c}21.20^{* *} \\
*\end{array}$ & $\begin{array}{c}11.41 * * \\
*\end{array}$ & $\begin{array}{c}4.07^{* *} \\
*\end{array}$ \\
\hline & \multirow{3}{*}{ Violent } & Start & $5.62 * * *$ & $14.16^{* * *}$ & $\begin{array}{c}241.88^{* *} \\
*\end{array}$ & $\begin{array}{c}149.40^{* *} \\
*\end{array}$ & $\begin{array}{c}87.77 * * \\
*\end{array}$ & $\begin{array}{c}45.59 * * \\
*\end{array}$ & $\begin{array}{c}24.38^{* *} \\
*\end{array}$ & $\begin{array}{c}14.60^{* *} \\
*\end{array}$ & $\begin{array}{c}4.83 * * \\
*\end{array}$ \\
\hline & & During & $4.67 * * *$ & $10.65^{* * *}$ & $\begin{array}{c}168.35^{* *} \\
*\end{array}$ & $\begin{array}{c}105.30 * * \\
*\end{array}$ & $\begin{array}{c}63.13^{* *} \\
*\end{array}$ & $\begin{array}{c}34.19 * * \\
*\end{array}$ & $\begin{array}{c}18.96^{* *} \\
*\end{array}$ & $\begin{array}{c}10.52^{* *} \\
*\end{array}$ & $\begin{array}{c}3.82 * * \\
*\end{array}$ \\
\hline & & End & $6.07 * * *$ & $16.01 * * *$ & $\begin{array}{c}246.15^{* *} \\
*\end{array}$ & $\begin{array}{c}152.86^{* *} \\
*\end{array}$ & $\begin{array}{c}90.60 * * \\
*\end{array}$ & $\begin{array}{c}47.77 * * \\
*\end{array}$ & $\begin{array}{c}25.84^{* *} \\
*\end{array}$ & $\begin{array}{c}13.93^{* *} \\
*\end{array}$ & $\begin{array}{c}5.23 * * \\
*\end{array}$ \\
\hline & \multirow{3}{*}{ War } & Start & $6.37 * * *$ & $16.41^{* * *}$ & $\begin{array}{c}261.47 * * \\
*\end{array}$ & $\begin{array}{c}161.34 * * \\
*\end{array}$ & $\begin{array}{c}94.61 * * \\
*\end{array}$ & $\begin{array}{c}49.04 * * \\
*\end{array}$ & $\begin{array}{c}26.42 * * \\
*\end{array}$ & $\begin{array}{c}15.16^{* *} \\
*\end{array}$ & $\begin{array}{c}5.11 * * \\
*\end{array}$ \\
\hline & & During & $5.54 * * *$ & $12.49 * * *$ & $\begin{array}{c}187.79 * * \\
*\end{array}$ & $\begin{array}{c}115.55^{* *} \\
*\end{array}$ & $\begin{array}{c}67.53 * * \\
*\end{array}$ & $\begin{array}{c}34.85^{* *} \\
*\end{array}$ & $\begin{array}{c}18.86^{* *} \\
*\end{array}$ & $\begin{array}{c}10.34 * * \\
*\end{array}$ & $\begin{array}{c}3.55 * * \\
*\end{array}$ \\
\hline & & End & $6.75^{* * *}$ & $17.14 * * *$ & $\begin{array}{c}270.59^{* *} \\
*\end{array}$ & $\begin{array}{c}168.06^{* *} \\
*\end{array}$ & $\begin{array}{c}99.51 * * \\
*\end{array}$ & $\begin{array}{c}52.36^{* *} \\
*\end{array}$ & $\begin{array}{c}28.50^{* *} \\
*\end{array}$ & $\begin{array}{c}15.58^{* *} \\
*\end{array}$ & $\begin{array}{c}5.46^{* *} \\
*\end{array}$ \\
\hline & \multirow{3}{*}{$\begin{array}{l}\text { Violent } \\
\text { Break }\end{array}$} & Start & $5.92 * * *$ & $15.36^{* * *}$ & $\begin{array}{c}255.08^{* *} \\
*\end{array}$ & $\begin{array}{c}158.01 * * \\
*\end{array}$ & $\begin{array}{c}93.13^{* *} \\
*\end{array}$ & $\begin{array}{c}48.54^{* *} \\
*\end{array}$ & $\begin{array}{c}26.28^{* *} \\
*\end{array}$ & $\begin{array}{c}15.51^{* *} \\
*\end{array}$ & $\begin{array}{c}5.23^{* * *} \\
*\end{array}$ \\
\hline & & During & $5.26^{* * *}$ & $12.47 * * *$ & $\begin{array}{c}189.42^{* *} \\
*\end{array}$ & $\begin{array}{c}117.48^{* *} \\
*\end{array}$ & $\begin{array}{c}69.50^{* *} \\
*\end{array}$ & $\begin{array}{c}36.53 * * \\
*\end{array}$ & $\begin{array}{c}19.39^{* *} \\
*\end{array}$ & $\begin{array}{c}11.00^{* *} \\
*\end{array}$ & $\begin{array}{c}4.18^{* *} \\
*\end{array}$ \\
\hline & & End & $6.22 * * *$ & $16.12^{* * *}$ & $\begin{array}{c}250.39 * * \\
*\end{array}$ & $\begin{array}{c}154.81 * * \\
*\end{array}$ & $\begin{array}{c}90.63 * * \\
*\end{array}$ & $\begin{array}{c}46.93^{* *} \\
*\end{array}$ & $\begin{array}{c}24.08^{* *} \\
*\end{array}$ & $\begin{array}{c}13.26^{* *} \\
*\end{array}$ & $\begin{array}{c}4.66^{* *} \\
*\end{array}$ \\
\hline & \multirow{3}{*}{ Protracted } & Start & $5.81^{* * *}$ & $14.81^{* * *}$ & $\begin{array}{c}226.87^{* *} \\
*\end{array}$ & $\begin{array}{c}139.41 * * \\
*\end{array}$ & $\begin{array}{c}81.20^{* *} \\
*\end{array}$ & $\begin{array}{c}41.56^{* *} \\
*\end{array}$ & $\begin{array}{c}21.84^{* *} \\
*\end{array}$ & $\begin{array}{c}12.59 * * \\
*\end{array}$ & $\begin{array}{c}4.32 * * \\
*\end{array}$ \\
\hline & & During & $4.14 * * *$ & $10.30 * * *$ & $\begin{array}{c}150.53^{* *} \\
*\end{array}$ & $91.90^{* * *}$ & $\begin{array}{c}53.22 * * \\
*\end{array}$ & $\begin{array}{c}27.27 * * \\
*\end{array}$ & $\begin{array}{c}14.72 * * \\
*\end{array}$ & $8.57 * * *$ & $\begin{array}{c}3.04 * * \\
*\end{array}$ \\
\hline & & End & $5.68 * * *$ & $14.78 * * *$ & $\begin{array}{c}232.08^{* *} \\
* \\
\end{array}$ & $\begin{array}{c}143.77 * * \\
* \\
\end{array}$ & $\begin{array}{c}84.50 * * \\
* \\
\end{array}$ & $\begin{array}{c}44.17 * * \\
* \\
\end{array}$ & $\begin{array}{c}23.20^{* *} \\
* \\
\end{array}$ & $\begin{array}{c}12.29 * * \\
* \\
\end{array}$ & $\begin{array}{c}4.49^{* *} \\
* \\
\end{array}$ \\
\hline
\end{tabular}




\begin{tabular}{|c|c|c|c|c|c|c|c|c|c|c|c|}
\hline & \multirow{3}{*}{ Major Power } & Start & $6.29 * * *$ & $16.84 * * *$ & $\begin{array}{c}248.50 * * \\
*\end{array}$ & $\begin{array}{c}152.70 * * \\
*\end{array}$ & $\begin{array}{c}88.95^{* *} \\
*\end{array}$ & $\begin{array}{c}45.57 * * \\
*\end{array}$ & \multirow{2}{*}{$\begin{array}{c}24.34 * * \\
* \\
18.69 * * \\
*\end{array}$} & \multirow{2}{*}{$\begin{array}{c}13.95^{* *} \\
* \\
11.33^{* *} \\
*\end{array}$} & \multirow{2}{*}{$\begin{array}{c}4.52 * x \\
* \\
3.50 * \\
*\end{array}$} \\
\hline & & During & $4.86 * * *$ & $12.15 * * *$ & $\begin{array}{c}187.87 * * \\
*\end{array}$ & $\begin{array}{c}115.20^{* *} \\
*\end{array}$ & $\begin{array}{c}66.10^{* *} \\
*\end{array}$ & $\begin{array}{c}34.25^{* *} \\
*\end{array}$ & & & \\
\hline & & End & $6.39 * * *$ & $16.41 * * *$ & $\begin{array}{c}252.58^{* *} \\
*\end{array}$ & $\begin{array}{c}156.41^{* *} \\
*\end{array}$ & $\begin{array}{c}92.24 * * \\
*\end{array}$ & $\begin{array}{c}48.29 * * \\
*\end{array}$ & $\begin{array}{c}25.90 * * \\
*\end{array}$ & $\begin{array}{c}14.49 * * \\
*\end{array}$ & $\begin{array}{c}4.99 * * \\
*\end{array}$ \\
\hline & \multirow{3}{*}{ Grave Threat } & Start & $6.58 * * *$ & $16.14 * * *$ & $\begin{array}{c}238.91^{* *} \\
*\end{array}$ & $\begin{array}{c}146.58^{* *} \\
*\end{array}$ & $\begin{array}{c}85.11 * * \\
*\end{array}$ & $\begin{array}{c}43.24^{* *} \\
*\end{array}$ & $\begin{array}{c}22.76^{* *} \\
*\end{array}$ & $\begin{array}{c}12.85^{* *} \\
*\end{array}$ & $\begin{array}{c}4.54 * * \\
*\end{array}$ \\
\hline & & During & $5.65 * * *$ & $13.34 * * *$ & $\begin{array}{c}186.14^{* *} \\
*\end{array}$ & $\begin{array}{c}115.84 * * \\
*\end{array}$ & $\begin{array}{c}68.83^{* *} \\
*\end{array}$ & $\begin{array}{c}36.40 * * \\
*\end{array}$ & $\begin{array}{c}18.83^{* *} \\
*\end{array}$ & $\begin{array}{c}10.59 * * \\
*\end{array}$ & $\begin{array}{c}3.47 * * \\
*\end{array}$ \\
\hline & & End & $6.38 * * *$ & $16.54 * * *$ & $\begin{array}{c}247.64^{* *} \\
*\end{array}$ & $\begin{array}{c}153.62^{* *} \\
*\end{array}$ & $\begin{array}{c}90.83^{* *} \\
*\end{array}$ & $\begin{array}{c}47.65^{* *} \\
*\end{array}$ & $\begin{array}{c}25.23 * * \\
*\end{array}$ & $\begin{array}{c}13.49 * * \\
*\end{array}$ & $\begin{array}{c}4.82 * * \\
*\end{array}$ \\
\hline & \multirow{6}{*}{$\begin{array}{c}\text { Crisis } \\
\text { Severity }\end{array}$} & Start & $4.83 * * *$ & $11.68 * * *$ & $\begin{array}{c}195.72 * * \\
*\end{array}$ & $\begin{array}{c}120.57 * * \\
*\end{array}$ & $\begin{array}{c}70.60 * * \\
*\end{array}$ & $\begin{array}{c}36.41 * * \\
*\end{array}$ & $\begin{array}{c}19.13^{* *} \\
*\end{array}$ & $\begin{array}{c}12.07 * * \\
*\end{array}$ & $\begin{array}{c}3.80 * * \\
*\end{array}$ \\
\hline & & During & $4.22 * * *$ & $9.47 * * *$ & $\begin{array}{c}125.33^{* *} \\
*\end{array}$ & $77.13 * * *$ & $\begin{array}{c}45.62 * * \\
*\end{array}$ & $\begin{array}{c}24.41 * * \\
*\end{array}$ & $\begin{array}{c}13.57^{* *} \\
*\end{array}$ & $7.91 * * *$ & $\begin{array}{c}3.25 * * \\
*\end{array}$ \\
\hline & & End & $4.63 * * *$ & $12.25^{* * *}$ & $\begin{array}{c}197.64^{* *} \\
* \\
\end{array}$ & $\begin{array}{c}122.34^{* *} \\
* \\
\end{array}$ & $\begin{array}{c}71.89 * * \\
*\end{array}$ & $\begin{array}{c}37.61 * * \\
*\end{array}$ & $\begin{array}{c}19.34 * * \\
*\end{array}$ & $\begin{array}{c}10.47^{* *} \\
*\end{array}$ & $\begin{array}{c}3.79 * * \\
* \\
\end{array}$ \\
\hline & & & \multicolumn{9}{|c|}{ Panel B: Volatility (Squared Returns) } \\
\hline & & & \multicolumn{9}{|c|}{ Quantile } \\
\hline \multirow{7}{*}{$\begin{array}{l}\text { Predictor } \\
\text { Variable }\end{array}$} & & & 0.1 & 0.2 & 0.3 & 0.4 & 0.5 & 0.6 & 0.7 & 0.8 & 0.9 \\
\hline & \multirow{4}{*}{ All } & Start & $\begin{array}{c}460.64 * * \\
*\end{array}$ & $\begin{array}{c}253.44 * * \\
*\end{array}$ & $\begin{array}{c}153.52^{* *} \\
*\end{array}$ & $91.71 * * *$ & $\begin{array}{c}50.61 * * \\
*\end{array}$ & $\begin{array}{c}23.46^{* *} \\
*\end{array}$ & $\begin{array}{c}16.89 * * \\
*\end{array}$ & $9.74 * * *$ & $\begin{array}{c}4.14 * * \\
*\end{array}$ \\
\hline & & During & $\begin{array}{c}318.95 * * \\
*\end{array}$ & $\begin{array}{c}177.12 * * \\
*\end{array}$ & $\begin{array}{c}109.04 * * \\
*\end{array}$ & $66.53 * * *$ & $\begin{array}{c}38.06^{* *} \\
*\end{array}$ & $\begin{array}{c}18.99 * * \\
*\end{array}$ & $\begin{array}{c}13.34 * * \\
*\end{array}$ & $7.51 * * *$ & $\begin{array}{c}3.19 * * \\
*\end{array}$ \\
\hline & & End & $\begin{array}{c}464.36^{* *} \\
*\end{array}$ & $\begin{array}{c}256.65^{* *} \\
*\end{array}$ & $\begin{array}{c}156.36^{* *} \\
*\end{array}$ & $94.21 * * *$ & $\begin{array}{c}52.72 * * \\
*\end{array}$ & $\begin{array}{c}25.10 * * \\
*\end{array}$ & $\begin{array}{c}17.69 * * \\
*\end{array}$ & $9.16 * * *$ & $\begin{array}{c}3.84 * * \\
*\end{array}$ \\
\hline & & Start & $\begin{array}{c}533.50 * * \\
*\end{array}$ & $\begin{array}{c}293.43 * * \\
*\end{array}$ & $\begin{array}{c}177.49 * * \\
*\end{array}$ & $\begin{array}{c}105.90^{* *} \\
*\end{array}$ & $\begin{array}{c}58.29^{* *} \\
*\end{array}$ & $\begin{array}{c}26.90 * * \\
*\end{array}$ & $\begin{array}{c}19.11^{* *} \\
*\end{array}$ & $\begin{array}{c}10.38^{* *} \\
*\end{array}$ & $\begin{array}{c}4.19 * * \\
*\end{array}$ \\
\hline & \multirow[t]{2}{*}{ Violent } & During & $\begin{array}{c}368.64 * * \\
*\end{array}$ & $\begin{array}{c}204.32 * * \\
*\end{array}$ & $\begin{array}{c}125.42^{* *} \\
*\end{array}$ & $76.31 * * *$ & $\begin{array}{c}43.49 * * \\
*\end{array}$ & $\begin{array}{c}21.67 * * \\
*\end{array}$ & $\begin{array}{c}15.43^{* *} \\
*\end{array}$ & $8.56 * * *$ & $\begin{array}{c}3.52 * * \\
*\end{array}$ \\
\hline & & End & $\begin{array}{c}542.76^{* *} \\
*\end{array}$ & $\begin{array}{c}300.08 * * \\
*\end{array}$ & $\begin{array}{c}182.74 * * \\
*\end{array}$ & $\begin{array}{c}110.15^{* *} \\
*\end{array}$ & $\begin{array}{c}61.64^{* *} \\
*\end{array}$ & $\begin{array}{c}29.21 * * \\
*\end{array}$ & $\begin{array}{c}21.14^{* *} \\
*\end{array}$ & $\begin{array}{c}11.33 * * \\
*\end{array}$ & $\begin{array}{c}4.51 * * \\
*\end{array}$ \\
\hline
\end{tabular}




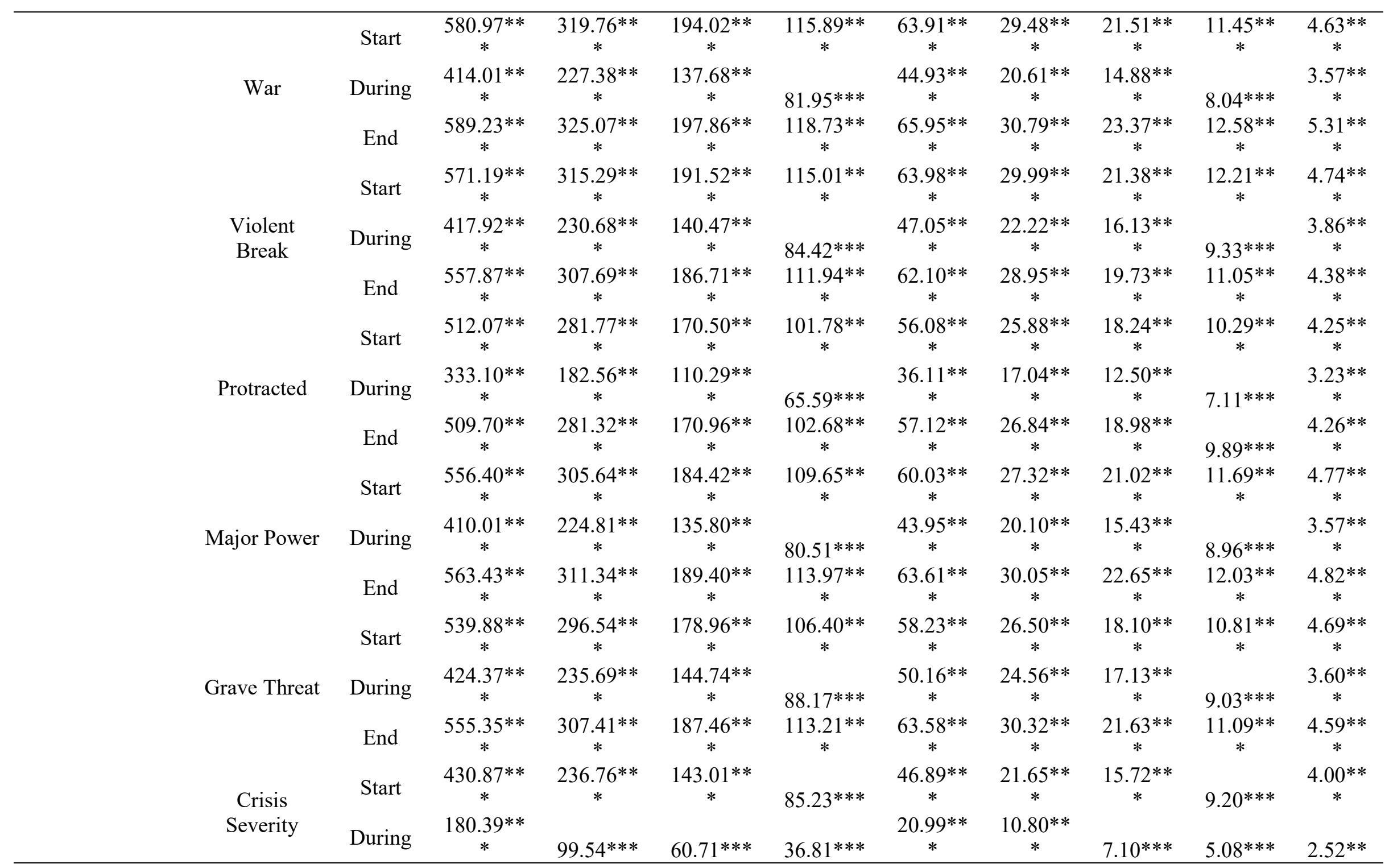




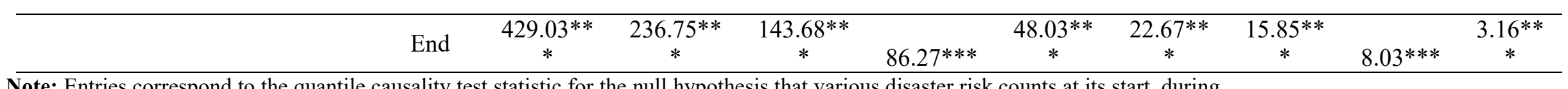

the quantile causality test statistic for the null hypothesis that various disaster risk counts at its start, during and end phases does not Granger cause oil returns and volatility; ***,**,* indicates rejection of null of no-causality at 1,5 , and 10 percent levels respectively.

\section{APPENDIX:}

Table A1. Causality-in-Quantiles Test for WTI Returns and Volatility (Squared Returns) Based on News-Based Measure of Disaster Risks (NVIX and Components)

\begin{tabular}{|c|c|c|c|c|c|c|c|}
\hline \multirow[b]{2}{*}{ Quantile } & \multicolumn{7}{|c|}{$\begin{array}{c}\text { Returns } \\
\text { Predictor Variable }\end{array}$} \\
\hline & NVIX & Government & Intermediation & $\begin{array}{l}\text { Natural } \\
\text { Disaster }\end{array}$ & $\begin{array}{l}\text { Securities } \\
\text { Markets }\end{array}$ & War & Unclassified \\
\hline 0.1 & $6.4206^{* * *}$ & $4.9679 * * *$ & $5.7493 * * *$ & $4.0758 * * *$ & $7.1407 * * *$ & $4.3490 * * *$ & $5.3588 * * *$ \\
\hline 0.2 & $12.9224 * * *$ & $10.6596^{* * *}$ & $13.4384 * * *$ & $10.5224 * * *$ & $18.0269 * * *$ & $11.5988 * * *$ & $11.4614 * * *$ \\
\hline 0.3 & $23.7779 * * *$ & $18.0387 * * *$ & $23.1145^{* * *}$ & $19.6249 * * *$ & $31.0261 * * *$ & $20.6908 * * *$ & $21.5147 * * *$ \\
\hline 0.4 & $102.5567 * * *$ & $79.8043 * * *$ & $104.6187 * * *$ & $106.6468 * * *$ & $117.4449 * * *$ & $113.2903 * * *$ & $100.5753 * * *$ \\
\hline 0.5 & $61.0115^{* * *}$ & $46.5777 * * *$ & $62.6492 * * *$ & $60.1245 * * *$ & $69.6136 * * *$ & $62.2860 * * *$ & $58.8065 * * *$ \\
\hline 0.6 & $32.9857 * * *$ & $25.2983 * * *$ & $34.8826^{* * *}$ & $29.6699 * * *$ & $37.4304 * * *$ & $30.3684 * * *$ & $30.9819 * * *$ \\
\hline 0.7 & $20.2650 * * *$ & $16.9381 * * *$ & $22.4840^{* * *}$ & $19.1358 * * *$ & $23.3822 * * *$ & $19.5013^{* * *}$ & $19.4769 * * *$ \\
\hline 0.8 & $11.7443 * * *$ & $10.1552 * * *$ & $13.2996 * * *$ & $10.8269 * * *$ & $12.8133 * * *$ & $11.9613 * * *$ & $11.1295 * * *$ \\
\hline \multirow[t]{2}{*}{0.9} & $4.4747 * * *$ & $4.4432 * * *$ & $5.0132 * * *$ & $4.1819 * * *$ & $4.9108^{* * *}$ & $4.1955^{* * *}$ & $4.3027 * * *$ \\
\hline & \multicolumn{7}{|c|}{$\begin{array}{c}\text { Volatility (Squared Returns) } \\
\text { Predictor Variable }\end{array}$} \\
\hline Quantile & NVIX & Government & Intermediation & $\begin{array}{l}\text { Natural } \\
\text { Disaster }\end{array}$ & $\begin{array}{l}\text { Securities } \\
\text { Markets }\end{array}$ & War & Unclassified \\
\hline 0.1 & $45.7090 * * *$ & $40.9852 * * *$ & $46.3816^{* * *}$ & $125.8735 * * *$ & $50.9710 * * *$ & $50.8902 * * *$ & $45.6798 * * *$ \\
\hline
\end{tabular}




\begin{tabular}{|c|c|c|c|c|c|c|c|}
\hline 0.2 & $28.1338 * * *$ & $25.4910 * * *$ & $28.2832 * * *$ & $68.6608 * * *$ & $30.8221 * * *$ & $29.8482 * * *$ & $27.9251 * * *$ \\
\hline 0.3 & $20.6017 * * *$ & $18.9120 * * *$ & $20.5306^{* * *}$ & $41.6931 * * *$ & $22.1305 * * *$ & $20.7916 * * *$ & $20.2640 * * *$ \\
\hline 0.4 & $16.5782 * * *$ & $15.4747 * * *$ & $16.3745 * * *$ & $25.5186 * * *$ & $17.3983 * * *$ & $15.9446 * * *$ & $16.1374 * * *$ \\
\hline 0.5 & $14.2497 * * *$ & $13.5339 * * *$ & $13.9418 * * *$ & $15.0452 * * *$ & $14.5919 * * *$ & $13.1595 * * *$ & $13.7264 * * *$ \\
\hline 0.6 & $13.1642 * * *$ & $12.9271 * * *$ & $13.0136^{* * *}$ & $9.5228 * * *$ & $13.5086 * * *$ & $12.1310^{* * *}$ & $12.6522 * * *$ \\
\hline 0.7 & $12.0080 * * *$ & $11.8190 * * *$ & $11.9256^{* * *}$ & $7.5614 * * *$ & $12.0319 * * *$ & $11.1460 * * *$ & $11.3894 * * *$ \\
\hline 0.8 & $10.2668 * * *$ & $10.0481 * * *$ & $9.9955 * * *$ & $5.0497 * * *$ & $10.0523 * * *$ & $9.1129 * * *$ & $9.8164 * * *$ \\
\hline 0.9 & $7.3948 * * *$ & $7.4433 * * *$ & $7.1194 * * *$ & $2.8865 * * *$ & $7.2265^{* * *}$ & $6.3844 * * *$ & $7.1151 * * *$ \\
\hline
\end{tabular}

Note: Entries correspond to the quantile causality test statistic for the null hypothesis that aggregate and components of news-based

volatility index (NVIX) does not Granger cause oil returns and volatility; $* * *, * *, *$ indicates rejection of null of no-causality at 1,5 , and

10 percent levels respectively.

Table A2. Causality-in-Quantiles Test for WTI Returns and Volatility (Squared Returns) Based on News-Based Measure of Geopolitical Risks

\begin{tabular}{cccc}
\hline \multicolumn{4}{c}{ Returns } \\
Predictor Variable \\
\hline Quantile & GPR & GPR Acts & Threats \\
0.1 & $4.3612^{* * *}$ & $4.7848^{* * *}$ & $4.6160^{* * *}$ \\
0.2 & $8.8046^{* * *}$ & $10.3587 * * *$ & $9.3838^{* * *}$ \\
0.3 & $15.3373^{* * *}$ & $20.1353^{* * *}$ & $15.5939^{* * *}$ \\
0.4 & $61.6984^{* * *}$ & $86.2895^{* * *}$ & $57.5383^{* * *}$ \\
0.5 & $39.8033^{* * *}$ & $54.1275^{* * *}$ & $37.3023^{* * *}$ \\
0.6 & $24.6144^{* * *}$ & $31.7634^{* * *}$ & $23.2817^{* * *}$ \\
0.7 & $15.7158^{* * *}$ & $20.0685^{* * *}$ & $14.9661^{* * *}$ \\
0.8 & $9.5360^{* * *}$ & $11.3614^{* * *}$ & $8.9023^{* * *}$ \\
0.9 & $4.5662^{* * *}$ & $4.6731^{* * *}$ & $4.4975^{* * *}$ \\
\hline \multicolumn{4}{c}{ Volatility (Squared Returns) }
\end{tabular}

Volatility (Squared Returns) 
Predictor Variable

\begin{tabular}{|c|c|c|c|}
\hline Quantile & GPR & GPR Acts & $\begin{array}{l}\text { GPR } \\
\text { Threats }\end{array}$ \\
\hline 0.1 & $54.9345^{* * *}$ & $78.5399 * * *$ & $54.8733 * * *$ \\
\hline 0.2 & $32.3526^{* * *}$ & $44.1667 * * *$ & $32.7087 * * *$ \\
\hline 0.3 & $22.3492 * * *$ & $28.6157 * * *$ & $22.8947 * * *$ \\
\hline 0.4 & $16.6481 * * *$ & $19.5465 * * *$ & $17.3002 * * *$ \\
\hline 0.5 & $13.2402 * * *$ & $13.8711 * * *$ & $13.9309 * * *$ \\
\hline 0.6 & $11.4198^{* * *}$ & $10.5223 * * *$ & $12.1437 * * *$ \\
\hline 0.7 & $10.7158 * * *$ & $10.0206^{* * *}$ & $11.0620 * * *$ \\
\hline 0.8 & $9.0443 * * *$ & $7.7320 * * *$ & $9.2269 * * *$ \\
\hline 0.9 & $6.3694 * * *$ & $5.5274 * * *$ & $6.6189 * * *$ \\
\hline
\end{tabular}

Note: Entries correspond to the quantile causality test statistic for the null hypothesis that aggregate and components of news-based geopolitical risks (GPRs) does not Granger cause oil returns and volatility; $* * *, * *, *$ indicates rejection of null of no-causality at 1,5 , and 10 percent levels respectively. 